\title{
The Strategy of China in Sino-African Relations
}

\author{
Sanibé Emmanuel Traoré \\ School of Politics and International Studies, Central China Normal University, Wuhan, China \\ Email: sanibe2@hotmail.co
}

How to cite this paper: Traoré, S. E. (2021). The Strategy of China in Sino-African Relations. Open Journal of Political Science, 11, 614-629.

https://doi.org/10.4236/ojps.2021.114039

Received: July 6, 2021

Accepted: September 3, 2021

Published: September 6, 2021

Copyright (c) 2021 by author(s) and Scientific Research Publishing Inc. This work is licensed under the Creative Commons Attribution International License (CC BY 4.0).

http://creativecommons.org/licenses/by/4.0/

\begin{abstract}
After a few years of cooperation, China has been able to build a very solid relationship with Africa. The Sino-African relationship is therefore far from being a gift from heaven or a gift on a gold platter, but it is the fruit of hard work of strict respect for diplomatic principles and therefore of a real sacrifice on the part of China. In other words, China has developed a grand strategy to maintain its relationship with African countries. Among these strategies we have trade with Africa, the creation of Confucius centers, the training of African executives in China, massive investments in Africa. In other words, China has been able to seduce Africa with its foreign policy and its soft power which has acquired popularity throughout the world today. However, China's strategy for Africa must still safeguard these bilateral relations and strengthen them against the Western rivalry which still remains jealous.
\end{abstract}

\section{Keywords}

Sino-African Relations, Confucius, Soft Power, Western, Rivalry

\section{Introduction}

Since the days of African independence, China was practically at the same level as the African countries. Only it was able to make the necessary reforms, thus allowing it to be the second economic power today. Among these reforms we have the "Great Leap Forward" of 1958-1963 and the break with the USSR (Stouder, 2014). However, its relations with Africa were not as developed as they are today although some links are really historic. Indeed, Sino African relations were decisive in the process of decolonization more precisely through the Bandung conference. In general, African countries are all linked to their colonizers even after independence. However nowadays China is the country which maintains the best relation with African countries. As being tired of exploitation and Western imperialism, African countries mostly turn to China. China is practically 
the second commercial partner of Africa. In the dynamism of this Sino-African relationship we note the creation of Confucius centers, the training of African executives in China (Benazeraf, 2014). We must also take into account the growth of Chinese investments in Africa. In other words, China has been able to seduce Africa with its foreign policy but also with its soft power which has acquired a good popularity throughout the world today. It is in this sense that we ask ourselves why China has been able to rise to such a level to compete with the colonizing powers of Africa in Africa. In other words, what exactly is the strategy for China's rise to power in Africa?

\section{Foundation of Sino-African Relations Ease of Use}

\subsection{Brief History of Sino African Relations}

First, confirm that you have the correct template for your paper size. This template has been tailored for output on the custom paper size $\left(21 \mathrm{~cm}^{\star} 28.5 \mathrm{~cm}\right)$.

Historically, Sino-African diplomacy dates back to 1955 , more precisely to the "Bandung Conference" in Indonesia where 29 states from Africa and Asia gathered around China. History shows that China-Africa relations are built on a solid foundation. That is why they are deeply rooted in the hearts of the people of both sides and have been soaked with all trials. The year 1949 therefore marks a new era for China-Africa relations. However, the links are fundamentally political in nature. At the crossroads of the colonial era and the start of African independence, China's interest in the African continent developed within the framework of Third World solidarity, in the face of the Western powers, in the wake of the Bandung conference (Bart, 2011).

This was a historic turning point in South-South relations. Bandung was an opportunity for China to brandish the principles of peaceful coexistence, the basis of a new political and economic era focused on emancipation and solidarity among poor countries. Note that South Africa, considered racist, Taiwan, infrequent for the Chinese, Israel considered anti-Arab, and the two Koreas (one too pro-American, the other too dictatorial) had not been invited. The principles stemming from Bandung constitute the first step of Sino-African solidarity. "Historically, one of the flagship projects and symbol of this solidarity for the people of Africa is the Tanzania-Zambia railway, known as the 'Freedom Road', which has been operating for more than thirty years now. This is why the Chinese engineer $\mathrm{Mr}$. Du Jian said that the "Tanzania-Zambia Railway is a monument of China-Africa friendship; he must continue to exist" (Rucai, 2016), This achievement carried the commitments of Bandung in the $60 \mathrm{~s}$. Chinese aid has helped to open up these two countries and end their political dependence by developing their own economies on the basis of South-South assistance. "We also have the ideological heritage of the Cold War, indeed during the Cold War; China will reorient its foreign policy in Africa according to the political choices of African heads of state vis-à-vis Taiwan, and this, against the great principles 
of Bandung. China has adapted its diplomatic tool according to the opportunities offered by the end of the Cold War, including the opening of markets in order to secure its access to the resources of the African continent. In 1963, Zhou En-Laï visited ten African countries, providing support to the populations (Snégaroff, 2015). China offers cooperation based on communist ideology, a source of success, on condition that it is supported and promoted by the states. In 1971, Africans seduced by this discourse of independence, neutrality and non-alignment voted overwhelmingly in favor of China's accession to the United Nations. So China has been very involved in the decolonization of Africa. With the independence of the former European colonies, China is often called upon to provide financial and military aid. The political character of China-Africa relations was accentuated during the Cold War. The West is reluctant to diplomatic relations between Beijing and various African countries. With the Sino-Russian split, Beijing and Moscow are vying for influence over Africa. Beijing thus supported between 1960 and 1970 several African liberation movements, which is far from pleasing the United States and Russia. China also maintains a significant development aid policy. In the 1980s, the African continent was a stake between the island of Taiwan and China. A dozen African countries had recognized the Taiwanese Republic, including South Africa, its most important partner. In 1998, South Africa gave up its important trade relations in favor of the diplomatic recognition of China. Other African countries then followed suit (Gazibo \& Mbabia, 2011). In the 1980s and 1990s, China turned away from Africa to focus on its own development. From the mid-1990s, the Chinese returned and invested heavily in Africa.

Denouncing both the practices of the Soviet camp and those of the Western camp, and anxious to counter their hegemony on the continent, China has proposed a third way to African governments (Huchet, 2013). This is about the model of cooperation, recognition and mutual respect, that will be based on eight main principles previously announced in 1964 in Accra by Zhou Enlai such us equality between partners, mutual benefits, respect for sovereignty, use of donations or interest-free loans and reduction of charges, strengthening of the beneficiary, equal treatment between Chinese and local exports. While their meaning has changed since this first phase of the Sino-African relationship, these principles still form the theoretical foundation that still guides and largely governs Chinese aid to Africa (Delcourt, 2019).

\subsection{The Choice of Coherent Principles}

The rise of China in Africa is mainly explained by the quality and strength of its diplomacy in Africa. This diplomacy was based on the promotion of the principles of non-interference and neutrality including the 5 founding principles of Chinese Diplomacy. For example, in 1953, Chinese Prime Minister Zhou En-Laï the African, had stated the "five principles of peaceful coexistence" that the Chinese intended to apply with regard to Asian, African and Latin American coun- 
tries which are independent or in the process of becoming (Chine Magazine, 2018) to become. These five principles are: mutual respect for sovereignty and territorial integrity; mutual non-aggression; non-interference in the internal affairs of sovereign states, equality and reciprocity of benefits derived from joint operations; peaceful coexistence. Supporting decolonization gave China an unprecedented opportunity to forge political, economic and cultural contacts with Africans. The principles of peaceful coexistence served as the basis for the organization of the Bandung conference. The respect of these principles by China makes today the greatness and the effectiveness of the bonds which exist between China and the African countries. It should also be noted that thanks to these principles China is catching up with Westerners in Africa, particularly France and the United States. Indeed, if the West acts in an imperialist way in Africa, China acts in a sincere, respectful and friendly way.

\subsection{Promotion of Chinese Soft Power}

China owes its rise to power to its soft power. Indeed, since the XVIIth Congress of the Chinese Communist Party in 2007, China's soft power strategy has been formalized around an intense promotion of China, in its cultural and diplomatic aspects but also an affirmation of the power of China that is more and more uninhibited (Courmont, 2012). Beijing is thus using Joseph Nye's concept as a tool in the service of its international ambitions. Soft power is a real strategy for China to gain momentum on the international scene, including Africa. To the Chinese, soft power means anything outside of military and security fields, including not only popular culture and public diplomacy, but also coercive and diplomatic economic levers like aid and investment. "This is why a US Congressional Research Service report states that China's soft power in Southeast Asia "largely derives from its role as a major source of foreign aid, of trade (Barr, 2017)." In view of the Chinese rise in the world and in Africa, soft power is like a threat against Western policies, especially American policies.

Thanks to its soft power, China has the largest diplomatic representation (embassies, consulates, diplomats) on the continent (Struye, 2009). During his tenure, President $\mathrm{Hu}$ Jintao visited no less than 17 African countries during the period 2006-2007. In 2009, according to the tradition of recent years, the Chinese leader's first overseas trip was elsewhere to Africa. Soft power is reflected in the taste of the Chinese language through the Confucius Institutes, African universities are organizing more and more courses to learn Chinese. China is also opening clinics and hospitals. China offered the construction of the African Union headquarters at the end of 2008 (for an amount of 120 million dollars). It still grants numerous scholarships to African students for studies in China (Lafargue, 2008). Thus China was able to count on African voices at the United Nations at the level of the permanent seat on the Security Council.

Another factor is the peaceful strategy. This peaceful ascent was developed by a Wen Jiabao and Hu Jintao in 2003-2004. Indeed, China has always advocated 
harmony, inside and outside its borders, compromise and the peaceful resolution of disputes. This conflict avoidance strategy reflects a need for security. In addition, this strategy allows China to be respected by other countries (Cabestan, 2007-2008).

Having fallen victim to the Western invasion, China is well aware of the situation in African countries. This is why it is in the best position to help African countries. With this in mind, it has developed a clear diplomacy based on respectful principles.

\section{The Emergence Strategy of China in Africa}

\subsection{The Weakening of Western Powers}

Considering the rivalries between China and the West in Africa, mainly the United States and France, Beijing has developed strategies which consist in weakening the Western countries. The African policy of the PRC is also part of a broader framework of strategy of bypassing or weakening the Western powers or assimilated, and mainly the United States, in an international situation described in Beijing as "complex", that is to say, to decode the official terminology, not very favorable to the interests Chinese. The South-South dialogue advocated by the PRC therefore always refers to the Third World of the 1960s, a discourse all the more effective as it relies on the longevity of African elites. According to this point, China, an emerging power, can also preserve its status as spokesperson for developing countries, even if in reality, particularly within the World Trade Organization (WTO), their interests are very divergent. In this context, China's African policy wants to be distinguished by the official emphasis on respecting the interests of African countries as opposed to the traditional neocolonialist model. The White Paper on China's African Policy first published in Beijing in January 2006: "China is working to establish and develop a new type of strategic partnership marked by political equality and mutual trust, cooperation in an economic win-win spirit. This position takes up the general principles of peaceful coexistence which remain relevant for Beijing and is expressed in almost the same terms from the declaration published during Jiang Zemin's visit in 1996, to the founding of CACF (China-Africa Cooperation Forum) in 2006.

For the PRC, it is a question of developing exchanges, by increasing the number of high-level visits which underline the importance of Africa, of increasing aid "without political conditions", of urging the international community to increase its support, and to defend the role of Africa on the international scene. This strategy particularly concerns marginalized states, even quasi-rogue, to which China offers a strategic partnership based on the careful respect of non-interference, the rejection of any moral legitimacy of the West and the promotion of the concept. specificity of values, opposed to the universalism of Western principles. Beijing thus denounces any interference in African affairs. In Chinese discourse, this strategy is expressed by the defense of a more just economic and political order, 
which has an undeniable echo on the black continent. China is once again posing as a model, even a leader, playing on its specificity as "the world's greatest developing power" a position that no one can dispute today. This strategy also responds to the expectations of Africans who, since the end of the cold war, have only witnessed a withdrawal of the West. In this context Robert Mugabe said this in May 2005 on the occasion of the $25^{\text {th }}$ anniversary of Zimbabwe's independence: We must look to the East, where the sun rises. It is weakening and China is entering the scene. The comfortable place enjoyed by the United States and Europe in the past is gradually being reduced by the language, values, ideas, history and products of China which are rapidly being assimilated in Africa (Pigeaud, 2018). This is why, more and more African countries are turning to China and it is clear that certain powers such as the United States, France today tend to lose their monopoly in Africa to the benefit of China because the Africa is tired of Western colonial imperialism. Africa needs to live, Africa wants to stand up, Africa wants to walk and that is only possible with her sincere brother from China.

This is why for Fanny Pigeaud the summit which brought together China, almost all African countries is the logical continuation of the unprecedented financial commitment of the Asian giant in Africa. Not without risks, this Sino-African cooperation sheds light on the fiasco of Western policies on the continent. Fanny Pigeaud China Africa reveals the failure of Westerners (Pigeaud, 2018). Above all, she shows that cooperation is possible without exploitation.

\subsection{The Quality of Chinese Investments in Africa}

In 2004, Chinese investments in Africa amounted to 925 million dollars cumulative since 1979 for the year 2005 alone; their amount is 175 million dollars. These programs concern 820 companies established in 49 countries. If the government intends to encourage Chinese companies to invest in Africa, it is for the moment mainly for official investments which probably do not cover all Chinese activities in Africa of state-owned enterprises, at more than 50\% in the construction industry. The PRC has an undeniable cost advantage in this area (Niquet, 2006). For infrastructure development, Western and especially French companies, whose costs are more than 50\% higher than Chinese offers, can only be ousted. Outside the construction sector, Chinese investments are directed towards sectors of particular interest to the Chinese economy such as energy, raw materials and mining products and, increasingly, the agricultural sector. In the energy sector, China has a strong oil presence, particularly in Sudan, where the Greater Nile Petroleum Operational Company (GNPOC) is $40 \%$ owned by the Chinese state-owned China National Petroleum Corporation (CNPC). Chinese companies have also built a $1500 \mathrm{~km}$ oil pipeline and a refinery for the country as planned (Morin-Allory, 2007). China has also expanded its presence in Angola, in cooperation with BP, in Mali, as well as wherever there are opportunities to develop oil production, especially in the countries around the Gulf of Guinea 
where China, more and more often, is the second largest importer, behind the United States. In construction and public works, Beijing is present almost everywhere, notably through the Beijing Urban Construction Group, for projects theoretically relating to "aid", in particular the construction of stadiums, government buildings, prestigious hospitals, presidential residences, a traditional form of the Chinese presence which remains relevant today and nourishes the friendship between Beijing and the local authorities or in the construction of roads and bridges, railways or large hydraulic works, on infrastructure projects financed by international organizations (World Bank), or for activities linked to tourism (construction of hotels) in poorly stabilized areas (Sierra Leone). China is also building free zones to accommodate Chinese companies, for example in the textile industry in Mauritius. China is also investing in cement plants, which can also serve as a screen for mineral exploration. Regarding raw materials, the PRC is particularly present in the timber sector in Liberia, Gabon, Cameroon, Equatorial Guinea and the Democratic Republic of Congo (DRC). Since 2003 the Hong Kong Company Vickwood has taken control of Western companies in Congo and Cameroon, as well as their huge operating areas. Over $80 \%$ of African timber, whether or not exploited by Chinese companies, is exported to the PRC. As far as mining products are concerned, Chinese companies are particularly present in the copper and cobalt sector in the DRC, bauxite and aluminum in the Republic of Guineawith the mining cooperation of non-ferrous metals another State company in the region in addition to Chalco (China Aluminum Company). Beijing is also interested in uranium in Niger, where Cogema seems to have recently encountered difficulties in the face of Chinese offers in renewing its operating agreements. China is also the largest investor in Zimbabwe, which holds the world's second-largest ferrochrome reserves, along with Bao Steel. In short According to Henri-Louis VEDIE twelve countries benefit from Chinese investments in the exploitation of their mineral deposits, this concerns twenty deposits, because some countries have benefited from it on several sites (Vedie, 2017).

The telecommunications sector is another priority sector for Beijing, both civilian and military. In the DRC, the Congo-China Telecom Company, 51\% controlled by China, is setting up the Internet communication network (International Centre for Trade and Sustainable Development 11 June 2010. In this area, however, cooperation is possible with France via the Chinese branch of Alcatel, Alcatel Shanghai Bell. It was this company that won a $\$ 75$ million equipment contract in Ghana, in cooperation with Ghana Telecom. Chinese companies have invested heavily in the exploitation of agricultural land, which operates in complete autarky, through the Corporation for Food and Agrifood Industries of China, particularly in areas liberated by the withdrawal of former farmers from requisitioned land, as in Zimbabwe or Tanzania, Rwanda or South Africa. The PRC now controls more than 20,000 hectares of agricultural land, divided into around ten production centers. Agricultural production is intended for the local market, 
the Chinese market and even more so for the world markets. Chinese farms specialize in rice cultivation, market gardening or industrial (sisal) crops for export. The PRC also invests heavily in industries related to fishing and aquaculture (shrimp), particularly in Mozambique and Mauritania, where more than 1000 Chinese residents out of 1500 officially registered are said to work in the fishing sector (Niquet, 2006).

Beyond trade, Africa appears to be a privileged target for Chinese investment, a kind of springboard in the globalization strategy of large Chinese companies encouraged by the authorities: in $2004 \mathrm{Hu}$ Jintao also declared that globalization was a priority axis for the Chinese economy. Africa presents a particularly favorable situation for Chinese investments and companies. More often than not, therefore, there is only limited competition there because of the disaffection from the West that followed the end of the Cold War.

In recent years, China has asserted itself as a major player in Africa (Kernen, 2014). It has developed an aggressive market penetration strategy by exploiting, among other things, the loopholes in paternalistic relations long founded on areas of historical-political influence between Western powers and African countries. China, supported by its financial potential, has acquired important markets in many African countries. The success of its strategy is based on its cooperation policy, its ability to mobilize funds and its dynamism in the implementation of projects through the "state enterprises" that it continues to promote.

The costs charged by Chinese companies and the fact that Beijing favors "empty" areas where security, both for investments and for people, is poorly assured, greatly facilitate the Chinese offensive. China is taking risks that big Western companies cannot take. If the PRC is now Sudan's biggest customer for oil, it is also because Chinese companies have built the Sudanese oil industry, from exploration to refining and transportation. In Mali, the Chinese company Sinopec has undertaken prospecting operations without any assurance on the importance of the results. China also benefits, as with the establishment of privileged partnerships, from its total absence of conditions and requirements in terms of compliance with the rules of transparency or good governance, unlike the investment programs controlled by Western countries.

\section{African perception of China}

\subsection{Strategic Partner}

In view of the rise of China in Africa and reciprocal interests, we can affirm that China is the only strategic partner of Africa capable of promoting its development. In fact, according to Prof. General Daniel Schaeffer, the volume of investment has tripled since 2004 (Schaeffer, 2008). China is now present in Africa in the field of material deposits, minerals, construction, production infrastructure, as well as in goods. Consumption, wood, cotton, telecoms and logistics infrastructure: ports, airports, railways, roads, gas pipelines, etc. The banking sector and investment funds are dedicated to Africa (agriculture, infrastructure and basic 
industry. This Chinese partnership affects both the economic, diplomatic, military, scientific, technical, socio-cultural, medical, health and media sectors. In the economic field, Sino-African cooperation manifests itself in the fields of trade and finance. In the trade area: China has established a network of trading structures. According to a statement by Commander Mbaye Cissé, there are 49 Sino-African trade delegations and chambers of commerce, 11 investment and trade promotion centers on the African continent. China is also working to create a free trade zone with COMESA (Common Market for Eastern and Southern Africa) and develop economic and trade cooperation zones in African countries. Beijing clearly seeks to put itself on an equal footing with the AGOA (American Growth Opportunity Act, launched by the United States in 2006) or the European Union Africa Caribbean Pacific (EU-ACP) Agreements. Also on this subject, Commander Cissé describes the process of China's investment in Africa. First, the setting up of a joint venture with a local or international company acquires the exploitation or exploration rights; then, importation of equipment and labor from China build the necessary infrastructure. Note that the objective for China being the securing of resources, the concern for profitability takes a back seat. In the financial field, Jacques Van Minden explains: "In July 2007 the China Investment Corporation (CIC) was created and caused fever in the whole world because the reserves of China exceeded 1000 billion dollars (Harbulot, 2021). The Chinese government has decided to make a very small part-240 billion dollars at the disposal of this new company to invest in the whole world, without distinction: in Europe, in Africa. China has given itself the means to develop investments by setting up in 2000 a subsidiary of Eximbank (Chinese Import-Export Bank) in Khartom (Andrésy, Marteau, \& Raballand, 2010). On the diplomatic level we have the creation of several diplomatic missions. Nowadays China has strengthened its diplomacy with Africa through state visits and FOCAC). In the military field, China has pledged to train 15,000 Africans, many of whom are military between 2008 and 2010. In participating in UN-mandated peacekeeping operations, China has sent its first contingent. Through the MONUC (United Nations Mission in the DRC), in January 2003, a second contingent in Liberia (UNMIL) and recently in Mali, there are around 1,500 Chinese soldiers in Africa. Beijing has also provided financial assistance to the African Union in a rather symbolic way for the deployment of peacekeepers in Darfur.

On the commercial front, the inauguration of the first Chinese Chamber of Commerce in Africa, in Johannesburg at the beginning of 2010, is a symbol of the extraordinary rise of trade. On the commercial front, the inauguration of the first Chinese Chamber of Commerce in Africa, in Johannesburg at the beginning of 2010, is a symbol of the extraordinary rise of trade (Bart, 2011).

In the scientific and technical field, we have the "New Africa-Asia Strategic Partnership" It was proposed by President $\mathrm{Hu}$ Jintao and it was supposed to make possible the transfer of technology to Africa. In this way we can understand that this is the proof that China is not selfish towards Africa; it does not intend to 
dominate Africa as the Westerners do. It has also set up a special investment fund for Africa of USD 5 billion, combining Western-style technology with low labor costs and Chinese public subsidies, particularly in the telecommunications sector (Hugon, 2010). In the socio-cultural field, many African students are welcomed in China through professional training in Africa, Confucius Centers (5 in 2008) language training in Chinese. As of December 31, 2018, 541 Confucius Institutes and 1170 Confucius Classes were already established in 162 countries and regions around the world, including 59 Confucius Institutes in 44 African countries and 41 Confucius Classes in 18 African countries (Bankuwiha, 2020).

In the medical and health field, China has expressed its willingness to provide Africa with sustained medical assistance against AIDS, advocating a new morality as the most effective vaccine against AIDS. Finally, we note the creation of the first FM broadcasting structure in Africa in January 2006 in Nairobi. RCI (Radio Chine Internationale) inaugurated its first external editorial office. The CRTV (General Society of Radio and Television for the International Technico-Economic Cooperation of China, with headquarters in Gabon) Chinese policy in Africa is therefore global (economic, political, diplomatic, military) and places China on a solid footing. Equality with the powers established on the continent (Commandant Cédric Le Goff, 2017).

China is now a strategic partner for Africa because of the "One Belt, One Road" initiative. This is an initiative proposed by Chinese President Xi Jinping in 2013, and which aims to revitalize ancient trade routes that linked Asia, Africa and Europe and promote economic engagement and investment along these routes. In this specific case, it facilitates communications and investments and finances. The "One Belt, One Road" initiative is the best platform for China-Africa cooperation as Zhou Yuxiao said. The "One Belt, One Road" initiative and the Forum on China-Africa Cooperation can be described as the "two legs" of cooperation between China and Africa, and everyone knows that with two legs you walk naturally in a faster and more stable manner. They could also be compared to the two "engines" of an airplane, which will help Sino-African cooperation to fly higher and further and allow China and Africa to conduct effective cooperation at a higher level. At present, African countries are engaged in a process of industrialization and modernization, and the Beijing Summit is expected to focus on identifying priority areas and future directions of Sino-African cooperation, in particularly with regard to Africa's economic transformation and modernization needs, and help Africa cultivate its capacity for self-development and accelerate its process of industrialization and modernization (Lisa, 2017). From a strictly economic development perspective, we can say that Sino-African relations are beneficial because they help reintroduce Africa into international formal trade flows, from which it has been isolated for decades (Delcourt, 2008).

An interview with Xinhua Haggai Kanenga, from the School of Development Studies at the University of Zambia will say that Africa must support the Chinese initiative because it will be important in the achievements of the 2063 agenda of 
African Union, which improves economic infrastructure to stimulate development. This initiative came at a time when Africa was seeking to promote its economic integration. So for Mr. Kanenga, African countries should take advantage of this by taking advantage of China's rich experiences in infrastructure development (Lisa, 2017).

During the summit (FCSA-FOCAC) from September 3-4, 2018, many researchers from the diplomatic world affirmed that Sino-African relations have become a model of unity and cooperation with developing countries, and a model of South-South cooperation. China has always attached great importance to the development of relations with African countries. She has always stood alongside Africa and other developing countries and has always been a sincere friend and reliable partner of Africa, according to Xu Jinghu the special representative of the Chinese government for African affairs asserted that the proposal of a concept of true and sincere politics and a correct vision of justice and profit towards Africa made by President Xi Jinping in 2013 has been warmly received by African countries. In recent years, this concept has become the general guiding principle of China in strengthening its solidarity and cooperation with developing countries. Thus, Sino-African relations have become a model of solidarity and cooperation between China and developing countries as well as a model of SouthSouth cooperation.

In view of the importance of FOCAS, China is arguably Africa's strategic partner. Eighteen years after its creation, it has never ceased to develop in a wider and deeper direction and has become an important platform for collective dialogue and pragmatic cooperation with African countries.

\subsection{Model of Emerging Power}

Being the second economic power, China has a very impressive level of development. It is therefore characterized by the rise of its industry and its economy, and by the challenges of its market. According to official sources, its economic growth is $9 \%$ per year (Lemoine, 2005). Not only is China well and truly "awakened", but the evolution and exponential progress of its economy is accompanied by a contagious dynamism liable, even, to upset the current global balances structured around the major industrialized countries and the interests of the latter. It is becoming an increasingly essential partner.

So Contrary to what some are beginning to imagine, China remains a model for Africa because it has had to go through the same phases that Africa finds itself in today. It is therefore not seen only as a potential investor but also as an emerging power from which Africa can draw inspiration to begin its development. China is also an emerging power with which Africa can cooperate even at the level of the United Nations. Moreover, for a long time, the People's Republic refused to talk about aid, preferring the terms "win-win cooperation" or "mutual assistance" between countries of the South. It was only in its White Paper on Development Assistance published in April 2011 that the Chinese government 
adopted this notion. China has for some time been the second economic power in the world, with growth of $10 \%$. This powerful role in the economy is accentuated by the size of the territory, its population, but above all by its rapid development strategy. Today it appears in the eyes of Africa as an emerging power because of its economic growth (Cabestan, 2013). This explosion in economic and trade relations has been accompanied by an unprecedented development of human relations between China and Africa, mutual respect. The main form of this boom has been the immigration of a large number of Chinese to this continent since the late 1990s ( 2 million to 5 million). At the same time, we also note an increasing number of Africans who go to China for example for the Canton Fair and to the Yiwu wholesale market in Zhejiang, Finally, Chinese tourism in Africa has appeared during the last decade, bringing more and more groups to animal parks in the east or south of the continent (Kenya, Tanzania, Botswana and especially South Africa). Although the proportion of Chinese visitors to Africa (2.3\% in 2010) remains low, the increase in their number is very rapid $(710,000$ in 2010 against 91,000 in 2000) and doomed to accelerate (Cabestan, 2013). So many developments like to encourage an increase in direct flights between China and the main airports on the African continent (Addis Ababa, Nairobi, Johannesburg). Also more and more African governments seek to boost their exports of manufactured products. It should also be noted that many African countries saw China as a useful counterweight to Western political and ideological influence until the Cold War era. Unfortunately, Africa still remains fragmented. Despite all these advances from Beijing, Africa has not become a "preserve" of the People's Republic either. Far from it, she still considers Africa as her brother, her friend.

Sino-African relations offer African countries a new horizon because above all China does not present any particular political demands, unlike France and the United States. It allows African countries to fully enjoy their sovereignty. Beijing leaves African countries free to vote at the United Nations (UN), it does not propose the deployment of soldiers on their soil and above all abstains from any lesson in democracy with regard to African governments. The foundation in 2000 of the Forum on Sino-African Cooperation (FOCSA) marks this desire for rapprochement. Almost all African states participate in this organization. China is committed to taking measures favorable to African economies (lowering customs duties, authorization of stays granted to Chinese tourists, etc.). The first meeting of this forum was held in Beijing in December 2000 and the second in Addis Ababa in December 2003 and the most recent in 2018.

\section{Prospects for Sino African Relations}

Faced with the uncertain future of Africa and the imperialist behavior of the West as well as their inability to respond to development challenges, we believe that African leaders must look to China, like the Ethiopian president. Meles Zelawi who expressed his willingness to go to China during Hu Jintao's African 
tour in 2007, "I think Westerners would be wrong to believe that they just have to buy good governance in Africa... China has cut this illusion to pieces. China is in no way endangering good governance reforms and democratization in Africa. Because only those who like China favored endogenous growth had any chance of success" (Zelawi, 2007). For this, we believe that FOCAS is a very good opportunity between China and Africa as Antonio Guterres said "FOCAC" is an extremely important tool in which Chinese leaders and African leaders can discuss issues of common interest (Guterres, 2018). According to United Nations Secretary-General Antonio Guterres, cooperation between China and Africa is an absolutely vital instrument for successful development in Africa. "Cooperation between Africa and China" is a central element of South-South cooperation. South-South cooperation is increasingly important in today's world as a fundamental tool to enable African countries to benefit from the remarkable success of China's economic development in recent decades". For the Algerian ambassador to China, Achene Boukhelfa, the length of the railways and that of the highways built in Africa by China through aid and funding have both exceeded 5000 kilometers in April 2017.

However, it is up to China and Africa to maintain this unique model of cooperation in the world. This means that China should not disappoint Africa. Africa too must rise to the occasion, offering good projects to China for financing by China and not trivial projects as some African countries often do. In addition, they must also improve their system of governance, starting with the fight against corruption but also despotism and clientelism.

China is willing to transfer technology to Africa. In addition, cooperation with Beijing is interesting as China's foreign policy and aid commitments become more and more sophisticated as they strengthen China's trade engagement (Davies, Edinger, Tay, \& Naidu, 2008). Cooperation also affects development, investment, economic and trade activities in Africa. China offers its know-how, manpower, low-interest loans and financial advantages to build infrastructure with its raw material suppliers. It does not limit its presence to African hydrocarbon producing countries. However, Africa must seize the opportunity of one Belt one Road "The Belt and the Road" to strengthen connectivity in rail and road port projects in telecommunications and information technology connectivity. Along with this idea, China must also promote African executives trained in China. Indeed, being the second world power, China is today one of the best countries in terms of technology, this is a knowledge, but also a weapon that it does not hesitate to bequeath to the thousands of African executives who come to form in the name of cooperation. Unfortunately, on their return they are still badly perceived. Some find it difficult to integrate and assert their skills in their respective countries. But this is due to the intoxication campaign carried out by potential rivals from China. Priority is generally given to executives trained in France or the USA for example. This is why we believe that China should take this into account because it is the cadres trained in China who can understand China's foreign policy in Africa and put it into practice with all its value. 
In fact, what you need to know is that the Sino-African relationship offers African countries a new horizon. Indeed, China does not present any particular political demands, unlike France and the United States, and allows African countries to fully retain their sovereignty. In order to maintain trade relations, China only asks that all ties with Taiwan be severed.

Despite their great support for African countries, Beijing leaves African countries free to vote at the United Nations (UN), does not propose the deployment of soldiers on their soil and above all abstains from any lesson in democracy. Regard to these governments. The foundation in 2000 of the Forum on Sino-African Cooperation (FOCSA) marks this desire for rapprochement. Almost all African states participate in this organization. China is committed to taking measures to promote African economies (lowering customs duties, authorization of stays granted to Chinese tourists, etc.).

\section{Conclusion}

The success of the Chinese strategy in Africa is no surprise. It should only be said that China has a good cooperation plan (win-win). This cooperation must be further strengthened and maintained so that the west can lose ground in Africa because as long as African countries are with the west, Africa will always be subjugated, visualized and dominated. Africa will always be in misery, in the wars and in imperialism which constitutes the essence of western relations because these powers never thought of the well-being of Africa let alone its development. This is why we believe that the Sino-African relationship is a unique example in the world and this model must be nurtured for the well-being of China and Africa. In a way, the Sino-African cooperation is one and only of its kind in the world only it still needs to be improved so that it can resist Western jealousy.

\section{Conflicts of Interest}

The author declares no conflicts of interest regarding the publication of this paper.

\section{References}

Andrésy, A., Marteau, J.-F., \& Raballand, G. (2010). La Chinafrique, mythes et réalité Dans Études.

Bankuwiha, E. (2020). Le rôle de l'Institut Confucius en Afrique Revue de l'Université du Burundi Série Sciences Humaines et Sociales $N$.

Barr, M. (2017). Études internationales Mythe et réalité du soft power de la Chine Études internationales.

Bart, F. (2011). Chine et Afrique, une longue histoire, une nouvelle donne géographique Revue de géographie de Bordeaux Les Cahiers d'Outre-Mer.

Benazeraf, D. (2014). Soft power chinois en Afrique, Renforcer les intérêts de la Chine au nom de l'amitié sino-africaine. Asie Visions (Ifri).

Cabestan, J. P. (2007-2008). Chine: Une diplomatie tous azimuts La Montée en puissance 
de la diplomatie chinoise, in S. Boisseau du. Rocher, La Documentation française.

Cabestan, J.-P. (2013). Les relations Chine Afrique: Nouvelles responsabilités et nouveaux défis d'une puissance mondiale en devenir Hérodote, $n^{\circ}$ 150, La Découverte.

Chine Magazine (2018, Juin). Les Cinq Principes de la Coexistence pacifique, Politique.

Commandant Cédric LE GOFF (2017). La Chine et l'Afrique: Lorsque l'opportunité occulte le risque JUIN Focas Iris.

Commandant Mbaye Cissé (2007). L'affirmation d'une stratégie de puissance: La politique africaine de la Chine. Diploweb.

Courmont, B. (2012). Le soft power chinois: Entre stratégie d'influence et affirmation de puissance. Revue d'études comparatives Est-Ouest, 43, 287-309.

Davies, M., Edinger, H., Tay, N., \& Naidu, S. (2008). How China Delivers Development Assistance to Africa. Centre for Chinese Studies.

Delcourt, L. (2019). La Chine Enjeux et perspectives CETRI. Centre Tricontinental.

Delcourt, L. (2008, Avril). La Chine en Afrique: Avantages ou inconvénients pour le développement? Cetri Les relations sino-africaines, exemplaires pour les relations internationales FCSA 2011.

Bart, F. (2011), Chine et Afrique, une longue histoire, une nouvelle donne géographique Édition Les cahiers d'outre-Mer Revue de géographie de Bordeaux. Chine: Regard croisé.

Gazibo, M., \& Mbabia, O. (2011). La politique africaine de la Chine montante à l'ère de la nouvelle ruée vers l'A frique Revue Études internationales 2 février 2011.

Guterres, A. (2018). L'ONU appelle la Chine et l'A frique à poursuivre une mondialisation juste et un développement durable inclusif ONU Info.

Harbulot, C. (2021). La stratégie de puissance de la Chine en Afrique Doc Player.

Hugon, P. (2010). Les nouveaux acteurs de la coopération en Afrique International Development Policy.

Huchet, J.-F. (2013). Huchet China Inc. Forces et limites de l'influence économique de la Chine Hérodote, $n^{\circ} 151$, La Découverte, 4e trimestre.

Kernen, A. (2014). L'Afrique face à la puissance économique de la Chine Politique africaine $\left(N^{\circ} 134\right)$.

Lafargue, F. (2008). La guerre mondiale du pétrole (p. 143). Ellipses.

Lemoine, F. (2005). La Chine, futur géant dans l'économie mondiale Revue Études (Tome 402).

Lisa (2017). L'Afrique devrait soutenir l'initiative "la Ceinture et la Route" Agence de presse Xinhua French.china.org.cn.

Morin-Allory, R. (2007). Chine-Soudan, une amitié à l'ombre des derricks Revue OutreTerre $\left(n^{\circ} 20\right)$.

Niquet, V. (2006). La stratégie Africaine de la Chine, article publié initialement dans Politique étrangère.

Pigeaud, L. F. (2018). Chine Afrique révèle l'échec des occidentaux Mediatpart.

Rucai, L. (2016, January 21). Témoin de l'histoire du chemin de fer Tanzanie-Zambie. Chineinfo.com.

Schaeffer, G. D. (2008). Dans Son allocution au Point de Veille $N^{\circ} 6$, Ecole Militaire.

Snégaroff, T. (2015). Quand la Chine partait à l'assaut de l'A frique (1963) France Infos le.

Stouder, P. (2014). La Chine et le Monde depuis 1949, Revue APHG.

Struye, T. (2009). Offensive chinoise en Afrique de Swielande UCL. 
Vedie, H.-L. (2017). Les investissements miniers chinois en Afrique Policy Center for the South International Centre for Trade and Sustainable Development (11 June 2010) L'Afrique, la Chine et l'Inde: Quelle coopération dans le domaine des TICs? Passerelles, Volume 11, Nimber 2.

Zelawi, M. (2007). FT interview avec le premier ministre. Financial Times. 